\title{
The Activity Concentrations and Radium Equivalent Activity in Soil Samples Collected from the Eastern Part of Basrah Governorate in Southern Iraq
}

\author{
Rasha S. Ahmed $\mathbb{D}^{1},{ }^{1}$ Raghad S. Mohammed ${ }^{D},{ }^{2}$ and Rana O. Abdaljalil ${ }^{2}$ \\ ${ }^{1}$ Department of Physiology and Medical Physics, College of Medicine, Al-Nahrain University, P. O. Box 70010, \\ Alkadhimiya, Baghdad, Iraq \\ ${ }^{2}$ Department of Physics, College of Science, Al-Mustansiriyah University, Baghdad, Iraq
}

Correspondence should be addressed to Rasha S. Ahmed; rasha_ryadh@yahoo.com

Received 20 March 2018; Accepted 24 April 2018; Published 28 May 2018

Academic Editor: Josef Havel

Copyright (C) 2018 Rasha S. Ahmed et al. This is an open access article distributed under the Creative Commons Attribution License, which permits unrestricted use, distribution, and reproduction in any medium, provided the original work is properly cited.

\begin{abstract}
Clay soil samples (0, 30, and $60 \mathrm{~cm}$ depths) were collected from two districts (Abu Al Khasib and Ad Dayr) in Basrah governorate in southern Iraq for gamma-ray spectroscopy. The activity concentrations for natural existing radionuclides in 18 soil samples were measured using high-purity germanium detector HPGe. From the obtained results of $\gamma$-ray spectroscopy, the ${ }^{238} \mathrm{U}$ activity concentrations were found to be ranging from 2.4 to $5.6 \mathrm{ppm}$ with an average of $3.5 \mathrm{ppm}$ in $\mathrm{Abu} \mathrm{Al}$ Khasib and ranging from 2.1 to $4.5 \mathrm{ppm}$ with an average of $2.9 \mathrm{ppm}$ in Ad Dayr. ${ }^{232}$ Th concentrations were ranging from 3.6 to $7.5 \mathrm{ppm}$ with an average of $4.7 \mathrm{ppm}$ in $\mathrm{Abu} \mathrm{Al} \mathrm{Khasib} \mathrm{and} \mathrm{ranging} \mathrm{from} 3.7$ to $7.9 \mathrm{ppm}$ with an average of $5.0 \mathrm{ppm}$ in Ad Dayr. ${ }^{40} \mathrm{~K}$ concentration was ranging from $0.1 \%$ to $2.0 \%$ with an average of $1.2 \%$ in Abu Al Khasib and ranging from $0.9 \%$ to $1.8 \%$ with an average of $1.3 \%$ in Ad Dayr. High ${ }^{238} \mathrm{U}$ and ${ }^{226} \mathrm{Ra}$ concentration levels were recorded in both study regions. The concentrations of ${ }^{232} \mathrm{Th}$ are within the normal limits in both regions. High levels of ${ }^{40} \mathrm{~K}$ were recorded in some locations. Generally, in most locations, ${ }^{40} \mathrm{~K}$ activity was within normal ranges. The radium equivalent activity, the external hazard index, the internal hazard index, and the radioactivity level index were calculated to estimate the radiation hazard in Basrah. The estimated radiation hazard indices were within normal limits, except the radioactivity level index, which shows elevated values. The obtained results were compared with other countries and with the worldwide median certified values.
\end{abstract}

\section{Introduction}

Human beings are exposed to natural radiation sources. The natural sources include the cosmic radiations that come from the sun that start as charged particles, which interact with the earth's atmosphere to produce gamma and beta radiations. Natural radioactive materials are also included in soil, water, and vegetation known as terrestrial radiation. In addition to the cosmic and terrestrial sources, humans also have radioactive isotopes inside their bodies since childbirth. Humans are also exposed to the man-made radiation used in medical processes such as radiation treatment, nuclear medicine, and diagnostic X-rays. Besides medical applications, manmade radiations are received from nuclear-power reactors and facilities involved in nuclear weapons. The major risky source is the usage of depleted uranium in weapons used in wars, which constitutes a great danger for the population. DU has a half-life of 4.4 billion years and is used in nuclear reactors and in the manufacture of nuclear weapons.

A number of factors affect the terrestrial radiation exposure such as the concentration of radionuclides in soil. The most essential primal radionuclides are ${ }^{238} \mathrm{U}$ with half-life of $4.5 \times 10^{9}$ years, ${ }^{232} \mathrm{Th}$ with half-life $1.405 \times 10^{10}$ years, and ${ }^{40} \mathrm{~K}$ with half-life of $1.277 \times 10^{9}$ years [1]. The concentration of radionuclides in air, water, soil, and rock were discussed in several studies [2-5].

Basrah, a city in southern Iraq of 1.6 million and 19.070 $\mathrm{km}^{2}$, has suffered from the spread of cancerous injuries and birth defects. High number of cancer cases among whom are children who are more sensitive to radiation than adults were 
TABLE 1: Samples regions, depths, and codes indices [7].

\begin{tabular}{|c|c|c|c|c|c|c|c|c|c|}
\hline \multicolumn{10}{|c|}{ Abu Al Khasib } \\
\hline Samples number & 1 & 2 & 3 & 4 & 5 & 6 & 7 & 8 & 9 \\
\hline Samples codes & A-S-1 & A-30-2 & A- $60-3$ & A-S- 4 & A-30-5 & A- $60-6$ & A-S-7 & A-30-8 & A- $60-9$ \\
\hline Depth of samples $(\mathrm{cm})$ & 0 & 30 & 60 & 0 & 30 & 60 & 0 & 30 & 60 \\
\hline \multicolumn{10}{|c|}{ Ad Dayer } \\
\hline Samples number & 10 & 11 & 12 & 13 & 14 & 15 & 16 & 17 & 18 \\
\hline Samples codes & D-S-1 & D-30-2 & D-60-3 & D-S-4 & D-30-5 & D-60-6 & D-S-7 & D-30-8 & D-60-9 \\
\hline Depth of samples $(\mathrm{cm})$ & 0 & 30 & 60 & 0 & 30 & 60 & 0 & 30 & 60 \\
\hline
\end{tabular}

recorded. A complete of 8,748 occasions were accumulated, $72.9 \%$ being residents of Basrah governorate, and $27.1 \%$ from an exterior. The documented numbers in the years 2005, 2006, 2007, and 2008 were $1,850,2,155,2,410$, and 2,333 cases, respectively, males and females accounting for $48.1 \%$ and $51.9 \%$ of cases [6].

Abu Al Khasib $\left(30.252{ }^{0} \mathrm{~N}, 48.0737{ }^{0} \mathrm{E}, 1152 \mathrm{Km}^{2}\right)$ and Ad Dayr $\left(30.829^{0} \mathrm{~N}, 47.574{ }^{0} \mathrm{E}, 825 \mathrm{Km}^{2}\right)$ are considered as an important agricultural districts in Basrah. Additionally, Ad Dayer is deemed to be a significant archaeological and religious region and visited by many tourists each day. Formerly, we use the same samples that we will adopt in this work [7] to estimate the activity concentrations in $\mathrm{Bq} / \mathrm{kg}$; the average outdoor external dose, average indoor external dose, total average value of the external dose, average annual outdoor effective dose, average annual indoor effective dose, and averaged total annual effective dose have been estimated. Values for total average value of the external dose and averaged total annual effective dose were higher than the worldwide median in both regions. Additionally, the excess lifetime cancer risk has been also assessed and found to be higher than the worldwide averages.

As both areas are important and considered as a source to equip the Iraqi provinces with agricultural crops, this work has been adopted to extend the results obtained in previously published work [7], to estimate additional radiation hazard indices that may affect the human health. In the present study, we aim to estimate the activity concentrations for radionuclides in ppm in clay soil samples for ${ }^{238} \mathrm{U},{ }^{226} \mathrm{Ra},{ }^{232} \mathrm{Th}$, and ${ }^{40} \mathrm{~K}$ and compared the results with the international confirmed surveys. Moreover, to distinguish regions that might be radiologically unsafe, the radium equivalent activity, the external hazard index, the internal hazard index, and the radioactivity level index were estimated and compared with each other and with worldwide estimated values.

\section{Materials and Methods}

2.1. Sample Collection and Preparation. A total of 18 (9 from Abu Al Khasib and 9 from Ad Dayr) clay soil samples were collected from the study regions as shown in Figure 1 [7]. As shown in Figure 1, only three sites were indicated in each of the sampling regions, since, from each indicated site, three samples were collected from $(0,30,60 \mathrm{~cm})$ depths using a plastic hand trowel. In each study region, a $1 \mathrm{~m}^{2}$ sampling

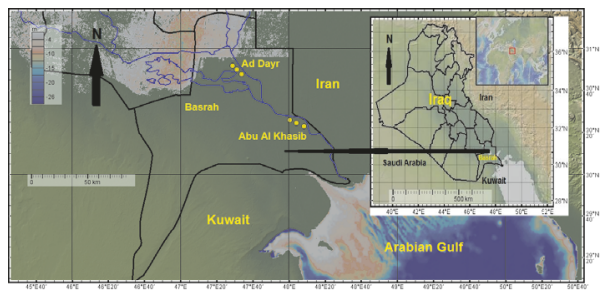

FIgURE 1: Map of the surveyed area conducted using geomapapp [7].

site was covered, each site located $1 \mathrm{~m}$ straight forward from the other. Samples were positioned in coded black plastic case about $1 \mathrm{~kg}$ each. The code's explanations are listed in Table 1. Samples were air-dried up on a paten for five days until every wetness was dissolved. The moisture-less samples then ground to soften fine powder employing a grinder and sifted through a $(2 \mathrm{~mm})$ mesh and stored for one month to permit total growth of ${ }^{226} \mathrm{Ra}$ with its daughters ${ }^{222} \mathrm{Rn},{ }^{214} \mathrm{~Pb}$, and

${ }^{214} \mathrm{Bi}$ before sending to Gamma Laboratory for the Ministry of Environment Radiation Protection Center (RPC) in Iraq, Baghdad.

2.2. Measurement by Gamma-Ray Spectrometry. In Gamma Laboratory, the activity concentrations for samples were measured using Canberra high-purity germanium (HPGe) detector, including mixed gamma source. The mixed gammaray source contains ${ }^{241} \mathrm{Am},{ }^{109} \mathrm{Cd},{ }^{57} \mathrm{Co},{ }^{57} \mathrm{Co},{ }^{139} \mathrm{Ce},{ }^{113} \mathrm{Sn}$, ${ }^{137} \mathrm{Cs},{ }^{88} \mathrm{Y},{ }^{60} \mathrm{Co},{ }^{60} \mathrm{Co},{ }^{85} \mathrm{Sr}$ radionuclides with their energies and activities listed in Table 2.

As it is arduous to split the recorded low activity samples signal from the background radiation, the calculations were carried out employing a $\mathrm{Pb}$ shielding with a settled bottom and portable cover. The results for all samples were estimated using the efficiency as a function of energy, the energy as a function of number of channels, and the full width half maxima FWHM as a function of number of channels calibrations. The efficiency calibration was performed using different energy peaks to cover the energy range from 60 up to $2500 \mathrm{keV}$ (Figure 2(a)). The efficiency $\epsilon$ of the counting for energies $E$ utilized in the calculations is given by

$$
\begin{aligned}
\ln (\epsilon)= & -1.943 \times 10^{2}+1.264 \times 10^{2} \ln (E)-3.089 \\
& \times 10^{1} \ln E^{2}+3.309 \ln E^{3}-1.319 \times 10^{-1} \ln E^{4}
\end{aligned}
$$




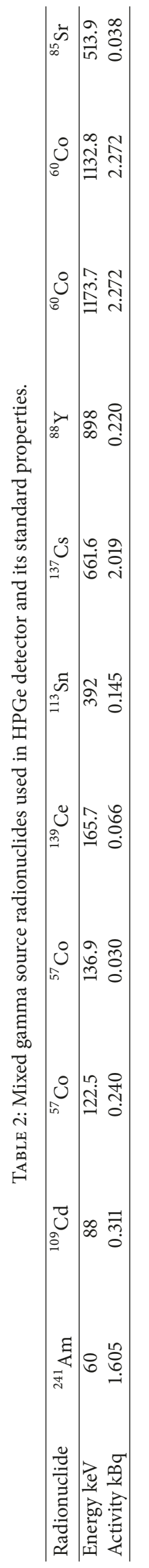




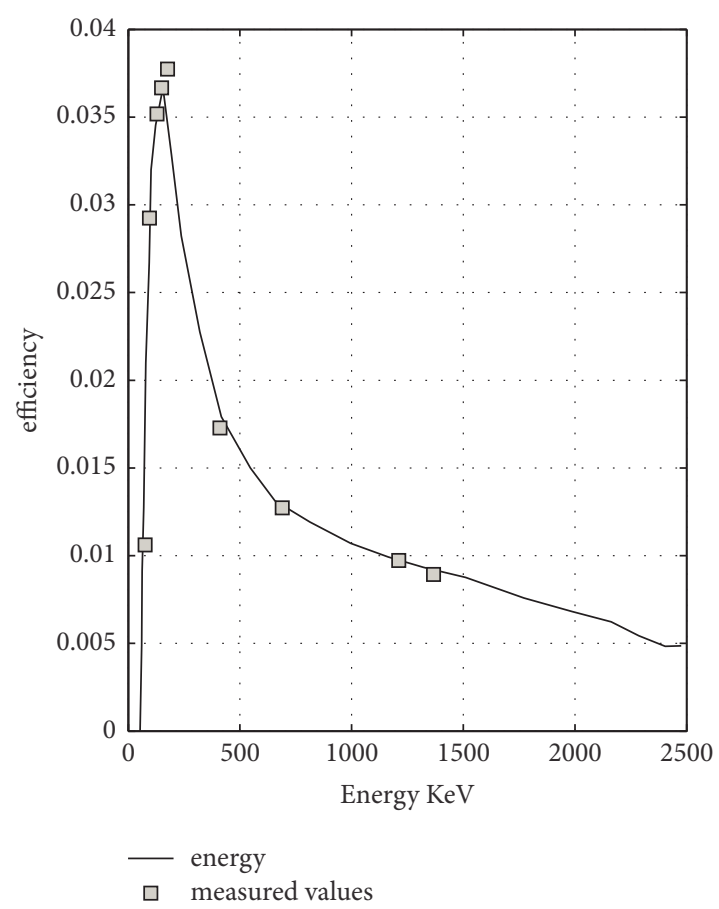

(a)

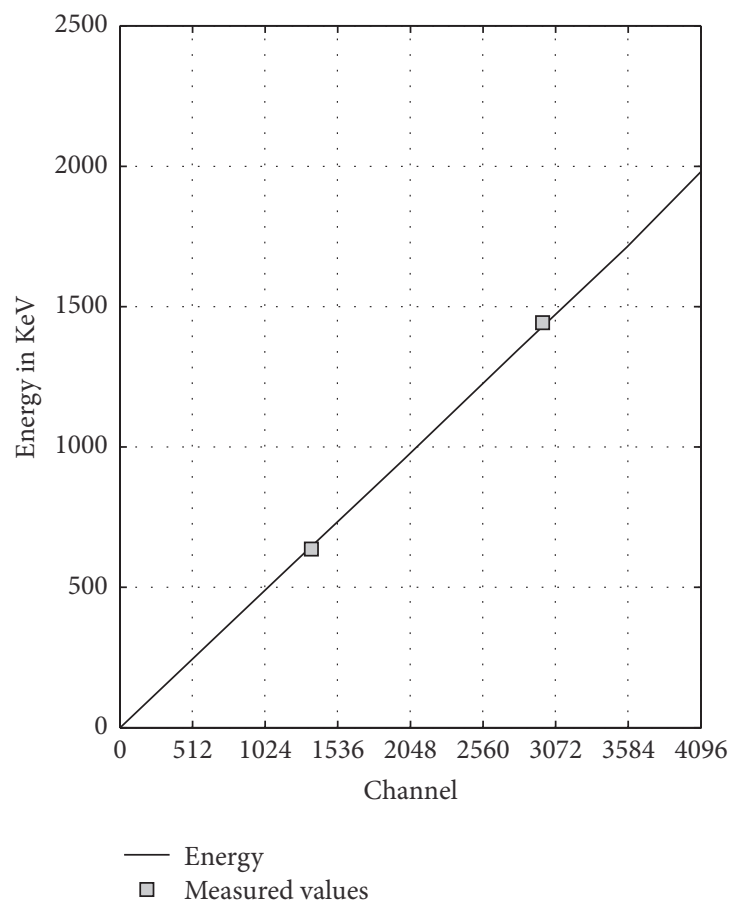

(b)

FIgure 2: (a) The linear scale of the efficiency calibration curve for HPGe detector (order of the polynomial is 4 with $R^{2}=0.709$ ). (b) The energy calibration curve for HPGe detector.

The energy calibration was established with 512, 1024, 1536, 2048, 2560, 3072, 3584, and 4096 channel numbers (Figure 2(b)) and well fitted with the first degree function as

$$
\text { Energy }=3.056 \times 10^{-1}+5.001 \times 10^{-1} \times \mathrm{Ch} \quad \mathrm{keV}
$$

Finally, the FWHM calibration performed uses the following expression:

$$
F W H M=6.013 \times 10^{-1}+3.517 \times 10^{-2} E^{1 / 2} \quad k e V
$$

The calibrations are saved and used in the acquisition program to apply the corrections for each sample.

The average activity concentration of ${ }^{238} \mathrm{U}$ was measured from the median peak energies of $351.9 \mathrm{keV}$ of ${ }^{214} \mathrm{~Pb}$ and $186.2 \mathrm{keV}$ of ${ }^{226} \mathrm{Ra}$. Correspondingly, the average activity concentration of ${ }^{232} \mathrm{Th}$ was estimated from the median peak energies of $238 \mathrm{keV}$ of ${ }^{212} \mathrm{~Pb}, 727.2 \mathrm{keV}$ of ${ }^{212} \mathrm{Bi}$, and 911.6 $\mathrm{keV}$ of ${ }^{228} \mathrm{Ac}$ [23]. All other radionuclides concentrations were estimated directly from its known peaks, as seen in Figures 3-5 for 1, 2, 3, 4,5,6 sample numbers. The calculated gamma spectra have been analyzed using Genie $2 \mathrm{k}$ Canberra software.

\section{Results and Discussions}

3.1. The Activity in Clay Soil from Abu Al Khasib and Ad Dayr. 18 clay soil samples were collected from the indicated locations in Figure 1 using Global Positioning System (GPS). Three samples were collected from each indicated site at 0,30 , and $60 \mathrm{~cm}$ depths. The measured activity concentrations of ${ }^{238} \mathrm{U},{ }^{232} \mathrm{Th},{ }^{40} \mathrm{~K}$ in the clay soil samples were listed in Table 3. The levels of general radioactivity due to isotopes were listed in $\mathrm{Bq} / \mathrm{kg}$ [7]. The concentrations of specific radioisotope in the samples were also measured in parts per million (ppm). Additionally, the maximum (max.), minimum (min.), average (ave.), standard deviation (stdev.), median (med.), and median absolute deviation (med. abs. div.) for the activity concentrations in $\mathrm{Bg} / \mathrm{kg}$ and ppm have been included.

The concentrations in ppm of ${ }^{238} \mathrm{U},{ }^{232} \mathrm{Th},{ }^{40} \mathrm{~K}$ were calculated from the measured activities in Bq/kg (Table 3) using the following experimental formula [24]:

$$
A(p p m)=C\left(\frac{B q}{k g}\right) \lambda=C\left[\left(\frac{M_{w}}{N \ln (2)}\right) t_{1 / 2}\right] \times 10^{6}
$$

where $\mathrm{C}$ is the activity concentration in $\mathrm{Bq} / \mathrm{kg}, M_{w}$ is the molecular weight $(\mathrm{g} / \mathrm{mol}), N$ is Avogadro's number, and $t_{1 / 2}$ is the half-life in seconds. The measured conversion factors $\lambda$ for each radionuclide has been listed in Table 4 , in addition to half-lives, and atomic masses used in the calculations.

Abu Al Khasib had 240,300 inhabitants and Ad Dayr 130,000 citizens in 2012. Statistics recorded a rise at the rate of birth defects from 3.2 cases per 1,000 births in 1990 to 22 cases per 1,000 births in 2000. Basrah witnessed the birth of 300 deformed children within one year [6]. In both Abu Al Khasib and Ad Dayr, the activity concentration has been measured and analyzed to focus on the radiological environment of both Abu Al Khasib and Ad Dayr.

Uranium can be found spontaneously in the environment in very little magnitudes in air, soil, rocks, and water. In 

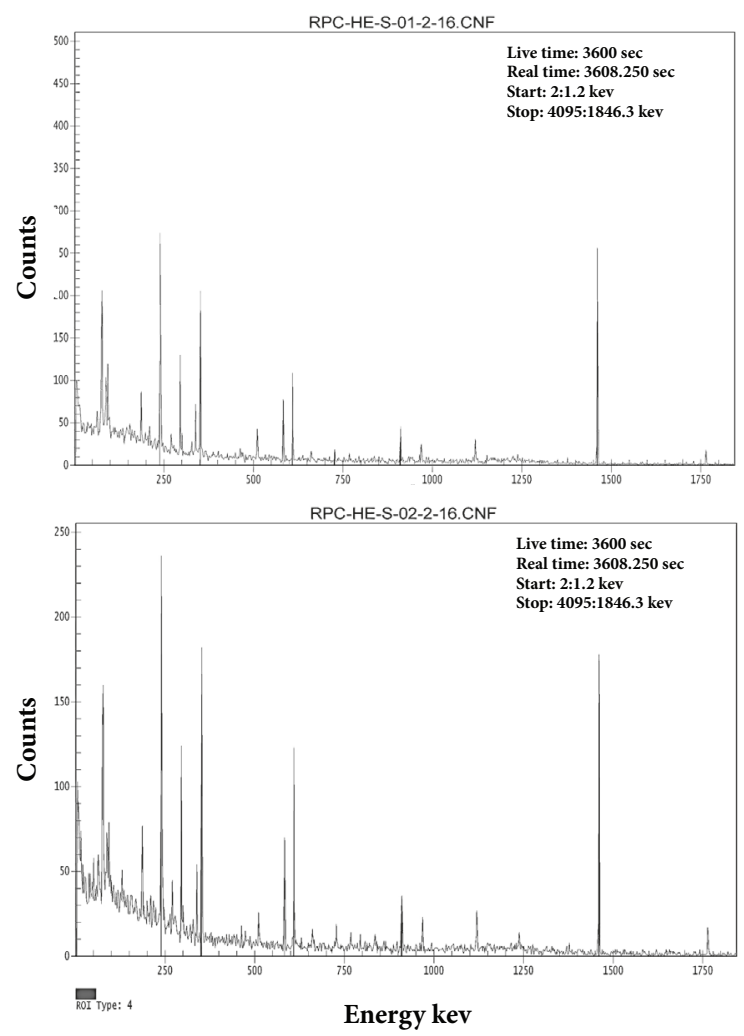

FIGURE 3: The number of counts as a function of energy of the radionuclides in samples 1 and 2, obtained by HPGe detector, and analyzed through Genie 2k Canberra software.
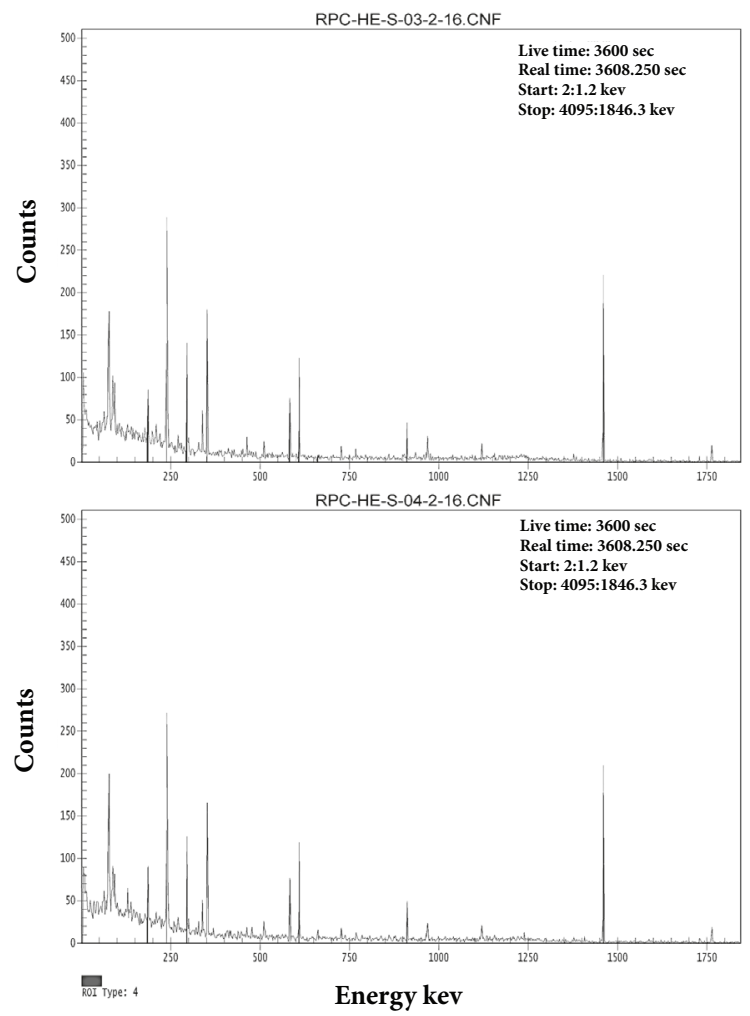

FIGURE 4: Same as Figure 3 for samples 3 and 4. 

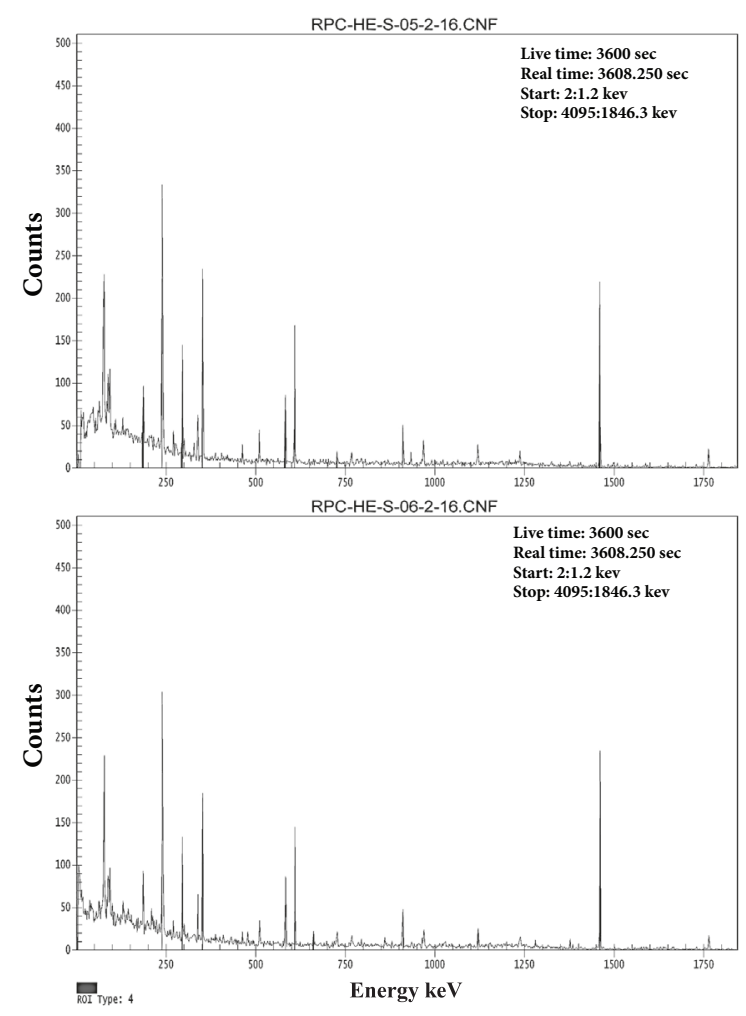

Figure 5: Same as Figure 3 for samples 5 and 6.

air, the uranium concentrations are very low. In water, most of the uranium is thawed uranium that is obtained from rocks and soil that the water moves over. The quantities of uranium in drinking water are usually low. Uranium is found in soils in changing concentrations that are typically very low. People constantly encounter exposure to a particular magnitude of uranium from food, air, soil, and water, as it spontaneously existed in all these elements. Individuals who settle nearby hazardous waste locations and eat yields farmed in contaminated soil may suffer a stronger exposure than other people. When humans are exposed to uranium radionuclides that are created throughout radioactive decay for a long interval, they possibly will develop cancer. The possibilities of obtaining cancer are much higher when persons are exposed to enriched uranium, since that is a further radioactive form of uranium. This form of uranium provides harmful radiation, which can cause people to evolve cancer within a few years.

As shown in Table $3,{ }^{238} \mathrm{U}$ activity concentration is ranging from $29.50(2.4 \mathrm{ppm})$ to $69.00 \mathrm{~Bq} / \mathrm{kg}$ (5.6 ppm) with an average of $43.56 \mathrm{~Bq} / \mathrm{kg}(3.5 \mathrm{ppm})$ in $\mathrm{Abu} \mathrm{Al}$ Khasib and ranging from $26.50(2.1 \mathrm{ppm})$ to $56.10 \mathrm{~Bq} / \mathrm{kg}$ (4.5 ppm) with an average of $35.53 \mathrm{~Bq} / \mathrm{kg}(2.9 \mathrm{ppm})$ in Ad Dayr. ${ }^{232} \mathrm{Th}$ concentration is ranging from $14.70(3.6 \mathrm{ppm})$ to $30.80 \mathrm{~Bq} / \mathrm{kg}$ (7.5 ppm) with an average of $19.39 \mathrm{~Bq} / \mathrm{kg}(4.7 \mathrm{ppm})$ in $\mathrm{Abu} \mathrm{Al}$ Khasib and ranging from 15.30 (3.7 ppm) to $32.20 \mathrm{~Bq} / \mathrm{kg}(7.9$ $\mathrm{ppm}$ ) with an average of $20.33 \mathrm{~Bq} / \mathrm{kg}(5.0 \mathrm{ppm})$ in Ad Dayr. ${ }^{40} \mathrm{~K}$ concentration is ranging from $25.80(0.1 \%)$ to 528.20
$\mathrm{Bq} / \mathrm{kg}(2.0 \%)$ with an average of $321.76 \mathrm{~Bq} / \mathrm{kg}(1.2 \%)$ in $\mathrm{Abu}$ $\mathrm{Al}$ Khasib and ranging from $241.80(0.9 \%)$ to $461.40 \mathrm{~Bq} / \mathrm{kg}$ $(1.8 \%)$ with an average of $337.02 \mathrm{~Bq} / \mathrm{kg}(1.3 \%)$ in Ad Dayr. The results of the activity concentrations in Bq/kg (Table 3 ) were compared with estimated values in the soil of different countries (Table 5). Furthermore, the worldwide average data were also included for comparison. High ${ }^{238} \mathrm{U}$ concentration levels were recorded in both study regions, greater than the world average and greater than some countries listed in the table. The concentrations of ${ }^{232} \mathrm{Th},{ }^{40} \mathrm{~K}$ are within the normal limits in both regions. In some locations (sites 1 and 6) high levels of ${ }^{40} \mathrm{~K}$ concentrations were recorded.

$R a$ exists at absolute low levels in the natural environ, substantially, in all rocks, soil, and water; furthermore, it is a decay product of uranium and thorium. Hence, where uranium and thorium appear at fairly elevated grades in rocks or soil, radium is as well found at elevated levels. As shown in Table $5,{ }^{226} \mathrm{Ra}$ activity ranging from 37.40 to $99.60 \mathrm{~Bq} / \mathrm{kg}$ with an average of $58.44 \mathrm{~Bq} / \mathrm{kg}$ in $\mathrm{Abu} \mathrm{Al}$ Khasib and ranging from 32.00 to $75.40 \mathrm{~Bq} / \mathrm{kg}$ with an average of $45.71 \mathrm{~Bq} / \mathrm{kg}$ in Ad Dayr. According to UNSCEAR report [10], extreme high levels of radium were recorded in both regions, higher than the world average and some of the countries included. Back to Figures 3, 4, and 5, cesium activities of 4.60 and $1.80 \mathrm{~Bq} / \mathrm{kg}$ were recorded in Abu Al Khasib (samples 3 and 6) and an activity of $1.10 \mathrm{~Bq} / \mathrm{kg}$ in Ad Dayr (sample 10).

In Table 6, the present study massic concentrations in clay soil of ${ }^{238} \mathrm{U},{ }^{232} \mathrm{Th}$, and ${ }^{40} \mathrm{~K}$ were compared with randomly 
TABLE $3:{ }^{238} \mathrm{U},{ }^{232} \mathrm{Th},{ }^{40} \mathrm{~K}$ activities in $\mathrm{Bq} / \mathrm{kg}$ [7] and the estimated values in ppm using $\gamma$-ray spectroscopy.

\begin{tabular}{|c|c|c|c|c|c|c|}
\hline \multicolumn{7}{|c|}{ Activity concentrations } \\
\hline \multirow{2}{*}{ Samples codes } & \multicolumn{2}{|c|}{${ }^{238} \mathrm{U}$} & \multicolumn{2}{|c|}{${ }^{232} \mathrm{Th}$} & \multicolumn{2}{|c|}{${ }^{40} \mathrm{~K}$} \\
\hline & $\mathrm{Bq} / \mathrm{kg}$ & ppm & $\mathrm{Bq} / \mathrm{kg}$ & ppm & $\mathrm{Bq} / \mathrm{kg}$ & ppm \\
\hline 1 & 58.6 & 4.7 & 26.9 & 6.6 & 522.1 & 2.0 \\
\hline 2 & 57.3 & 4.6 & 18.9 & 4.6 & 408.1 & 1.6 \\
\hline 3 & 40 & 3.2 & 18.5 & 4.5 & 296.6 & 1.1 \\
\hline 4 & 31.7 & 2.6 & 15.4 & 3.8 & 298.4 & 1.2 \\
\hline 5 & 38.3 & 3.1 & 17.2 & 4.2 & 240 & 0.9 \\
\hline 6 & 69 & 5.6 & 30.8 & 7.5 & 528.2 & 2.0 \\
\hline 7 & 31.3 & 2.5 & 16.8 & 4.1 & 303.4 & 1.2 \\
\hline 8 & 36.3 & 2.9 & 15.2 & 3.7 & 273.2 & 1.1 \\
\hline 9 & 29.5 & 2.4 & 14.7 & 3.6 & 25.8 & 0.1 \\
\hline $\max$. & 69.0 & 5.6 & 30.8 & 7.5 & 528.2 & 2.0 \\
\hline $\min$. & 29.5 & 2.4 & 14.7 & 3.6 & 25.8 & 0.1 \\
\hline ave. & 43.6 & 3.5 & 19.4 & 4.7 & 321.8 & 1.2 \\
\hline stdev. & 20.6 & 1.6 & 8.6 & 2.1 & 350.9 & 1.3 \\
\hline med. & 38.3 & 3.1 & 17.2 & 4.2 & 298.4 & 1.2 \\
\hline med. abs. div. & 7 & 0.6 & 1.8 & 0.4 & 58.4 & 0.3 \\
\hline 10 & 32.5 & 2.6 & 21.4 & 5.2 & 341.8 & 1.3 \\
\hline 11 & 27 & 2.2 & 17.3 & 4.2 & 300 & 1.2 \\
\hline 12 & 34.2 & 2.8 & 18.3 & 4.5 & 322 & 1.2 \\
\hline 13 & 28.9 & 2.3 & 17.3 & 4.2 & 241.8 & 0.9 \\
\hline 14 & 56.1 & 4.5 & 32.2 & 7.9 & 461.4 & 1.8 \\
\hline 15 & 30.6 & 2.5 & 15.3 & 3.7 & 321.4 & 1.2 \\
\hline 16 & 32 & 2.6 & 20.8 & 5.1 & 309.8 & 1.2 \\
\hline 17 & 52 & 4.2 & 24.1 & 5.9 & 450.2 & 1.7 \\
\hline 18 & 26.5 & 2.1 & 16.3 & 4.0 & 284.8 & 1.1 \\
\hline $\max$. & 56.1 & 4.5 & 32.2 & 7.9 & 461.4 & 1.8 \\
\hline $\min$. & 26.5 & 2.1 & 15.3 & 3.7 & 241.8 & 0.9 \\
\hline ave. & 35.5 & 2.9 & 20.3 & 5.0 & 337.0 & 1.3 \\
\hline stdev. & 4.2 & 0.4 & 3.6 & 0.8 & 40.3 & 0.1 \\
\hline med. & 32 & 2.6 & 18.3 & 4.5 & 321.4 & 1.2 \\
\hline med. abs. div. & 3.1 & 0.3 & 2.5 & 0.6 & 21.4 & 0.1 \\
\hline
\end{tabular}

TABLE 4: The half-lives, atomic masses, and the calculated radioactivity conversion factors from $\mathrm{Bq} / \mathrm{kg}$ to $\mathrm{ppm}$ for ${ }^{238} \mathrm{U}$, ${ }^{232} \mathrm{Th},{ }^{40} \mathrm{~K}$ radionuclides.

\begin{tabular}{lccc}
\hline radionuclide & Half-life (years) & Atomic mass $(\mathrm{u})$ & $\lambda$ \\
${ }^{238} \mathrm{U}$ & $4.5 \times 10^{9}$ & 238.05 & 0.080901 \\
${ }^{232} \mathrm{Th}$ & $1.405 \times 10^{10}$ & 232.03 & 0.246225 \\
${ }^{40} \mathrm{~K}$ & $1.277 \times 10^{9}$ & 39.96 & $3.8585 \times 10^{-3}$ \\
\hline
\end{tabular}

selected countries evaluations in clay soil around the world and with the worldwide averaged values. The averaged ${ }^{238} \mathrm{U}$ (ppm) concentration attained in this study is greater than the world average value and also greater than some listed countries. The concentration of ${ }^{232} \mathrm{Th}(\mathrm{ppm})$ is lower than the world average but higher than some listed countries. The $\mathrm{K}(\%)$ concentration is lower than the world average and lower than the listed countries. Both of the study locations are farming areas in which plowing and mixing of the soil take place to prepare it for agriculture; as a result, there is no particular order of contamination with depth.

3.2. The Radiation Hazard Indices. It is significant to evaluate the $\gamma$-ray radiation hazards of soil to human beings on $\mathrm{Abu} \mathrm{Al}$ Khasib and Ad Dayr. The $\gamma$-ray radiation hazards due to the natural radionuclides ${ }^{226} \mathrm{Ra},{ }^{232} \mathrm{Th}$, and ${ }^{40} \mathrm{~K}$ were assessed by various radiation hazard indices. Radium equivalent activity $R a_{e q}$ is widely used to identify the consistency of radiation 
TABLE 5: The average activity concentrations of ${ }^{238} \mathrm{U},{ }^{232} \mathrm{Th},{ }^{226} \mathrm{Ra}$, and ${ }^{40} \mathrm{~K}$ radionuclides in Bq/kg evaluated by R. S. Mohammed and R. S. Ahmed [7], compared with different countries and worldwide average.

\begin{tabular}{|c|c|c|c|c|c|}
\hline \multirow[t]{2}{*}{ Country } & \multicolumn{4}{|c|}{ The average activity concentrations $(\mathrm{Bq} / \mathrm{kg})$} & \multirow[b]{2}{*}{ reference } \\
\hline & ${ }^{238} \mathrm{U}$ & ${ }^{232} \mathrm{Th}$ & ${ }^{226} \mathrm{Ra}$ & ${ }^{40} \mathrm{~K}$ & \\
\hline Abu Al Khasib & 44 & 19 & 58 & 322 & [7] \\
\hline Ad Dayr & 36 & 20 & 46 & 337 & {$[7]$} \\
\hline Italy & - & 39 & 323 & 1,046 & {$[8]$} \\
\hline Turkey & 29 & 18 & - & 580 & [9] \\
\hline Spain & 33 & 49 & 45 & 650 & {$[8]$} \\
\hline Japan & 29 & 28 & 68 & 310 & {$[10]$} \\
\hline Belgium & - & 28 & 28 & 390 & {$[8]$} \\
\hline Mexico & 23 & 19 & - & 530 & {$[11]$} \\
\hline India & 26 & 51 & - & 5.6 & {$[12]$} \\
\hline Oman & 30 & 16 & - & 225 & [13] \\
\hline Algeria & - & - & 80 & 408 & {$[8]$} \\
\hline France & 37 & 38 & 38 & 599 & {$[8]$} \\
\hline Taiwan & 18 & 28 & - & 479 & {$[8]$} \\
\hline Jordan & 49 & 27 & - & 291 & {$[4]$} \\
\hline Egypt & 37 & 18 & - & 320 & {$[10]$} \\
\hline Qatar & 23 & 4.5 & - & 127 & {$[14]$} \\
\hline Thailand & 35 & 30 & - & 400 & {$[15]$} \\
\hline USA & 35 & 35 & - & 370 & {$[10]$} \\
\hline The Netherlands & - & 50 & - & 495 & {$[8]$} \\
\hline World & 35 & 30 & 35 & 400 & {$[10]$} \\
\hline
\end{tabular}

TABLE 6: A comparison of the mass concentrations of ${ }^{238} \mathrm{U},{ }^{232} \mathrm{Th}$, and ${ }^{40} \mathrm{~K}$ in clay soil samples evaluated in the present study with other locations around the world.

\begin{tabular}{|c|c|c|c|c|}
\hline Location & ${ }^{238} \mathrm{U}(\mathrm{ppm})$ & ${ }^{232} \mathrm{Th}(\mathrm{ppm})$ & ${ }^{40} \mathrm{~K}(\%)$ & references \\
\hline Present study (Abu Al Khasib) & $2.4-5.6$ & $3.6-7.5$ & $0.1-2.0$ & \\
\hline Present study (Ad Dayr) & $2.1-4.5$ & $3.7-7.9$ & $0.9-1.8$ & \\
\hline Cyprus & $0.08-7.2$ & $0.25-13.1$ & $0.04-2.91$ & [16] \\
\hline Italy & $0.16-5.6$ & $0.25-16.8$ & $0.03-5.14$ & [17] \\
\hline Bulgaria & $0.64-15.2$ & $1.73-39.5$ & $0.05-3.75$ & [18] \\
\hline Canada (Rock) & $0.8-16.4$ & $1.1-41.0$ & $1.0-6.2$ & {$[19]$} \\
\hline Jordan & $1.76-8.32$ & $5.18-25.4$ & $0.45-1.96$ & [20] \\
\hline USA & $0.32-11.2$ & $0.98-32.1$ & $0.32-2.28$ & {$[18]$} \\
\hline Egypt & $0.48-9.6$ & $0.49-23.7$ & $0.09-2.12$ & {$[18]$} \\
\hline Serbia and Montenegro & $1.2-6.24$ & $4.45-21.0$ & $0.88-2.99$ & {$[21]$} \\
\hline Albania & $0.48-7.68$ & $0.98-39.5$ & $0.05-3.75$ & {$[18]$} \\
\hline Australia & $1.6-3.8$ & 6-19 & $0.7-1.9$ & {$[22]$} \\
\hline World Average & 2.64 & 11.1 & 1.37 & {$[21]$} \\
\hline
\end{tabular}

exposure; consequently, any radium equivalent activity concentration that passes $370 \mathrm{~Bq} / \mathrm{Kg}$ may raise radiation hazards. In the present study, $R a_{e q}$ was determined in $\mathrm{Bq} / \mathrm{kg}$ using the following expression [25]:

$$
R a_{e q}\left(B q k g^{-1}\right)=0.077 C_{K}+C_{R a}+1.43 C_{T h}
$$

where $C_{K}, C_{R a}$, and $C_{T h}$ are the activities for potassium, radium, and thorium, respectively.

The $\mathrm{Ra}$ activity concentration and $R a_{e q}$ in $(\mathrm{Bq} / \mathrm{Kg})$ calculated for the samples under study are listed in Table 7. The recorded values are ranging from 60.46 to $184.32(\mathrm{~Bq} / \mathrm{Kg})$ with an average $110.94(\mathrm{~Bq} / \mathrm{Kg})$ in Abu Alkhasib and from 77.24 to $156.97(\mathrm{~Bq} / \mathrm{Kg})$ with an average $100.74(\mathrm{~Bq} / \mathrm{Kg})$ in Ad Dayer. These values are less than the approved maximum value in building materials of $350(\mathrm{~Bq} / \mathrm{Kg})$ [26]. Further important criterion used to estimate the level of gamma-ray radiation is defined by the external hazard index $\left(\mathrm{H}_{\mathrm{ex}}\right)$ and the internal hazard index $\left(\mathrm{H}_{\mathrm{in}}\right)$ which is defined as follows [26-28]:

$$
H_{e x}=\frac{C_{U}}{370 \mathrm{Bqkg}^{-1}}+\frac{C_{T h}}{259 \mathrm{Bqkg}^{-1}}+\frac{C_{K}}{4810 \mathrm{Bqkg}^{-1}}
$$


TABLE 7: The measured values for $R a_{e q}$ [7], $\mathrm{H}_{\text {ext }}, \mathrm{H}_{\text {in }}$ hazard indices in $(\mathrm{Bq} / \mathrm{Kg})$ and the radioactivity level index $\mathrm{I}_{\gamma}$ for 18 clay soil samples, in addition to its max., min., ave., stdev., med., and med. abs. div. values.

\begin{tabular}{|c|c|c|c|c|c|}
\hline $\begin{array}{l}\text { Samples } \\
\text { number }\end{array}$ & $\begin{array}{c}{ }^{226} \mathrm{Ra} \\
(\mathrm{Bq} / \mathrm{Kg})\end{array}$ & $\begin{array}{c}R a_{e q} \\
(B q / K g)\end{array}$ & $\begin{array}{c}H_{\text {ext }} \\
(B q / K g)\end{array}$ & $\begin{array}{c}H_{\text {in }} \\
(\mathrm{Bq} / \mathrm{Kg})\end{array}$ & $I_{\gamma}$ \\
\hline 1 & 76.8 & 155.50 & 0.42 & 0.63 & 1.13 \\
\hline 2 & 78.4 & 136.90 & 0.37 & 0.58 & 0.98 \\
\hline 3 & 58 & 107.29 & 0.29 & 0.45 & 0.77 \\
\hline 4 & 42.8 & 87.80 & 0.24 & 0.35 & 0.64 \\
\hline 5 & 44.8 & 87.88 & 0.24 & 0.36 & 0.63 \\
\hline 6 & 99.6 & 184.32 & 0.50 & 0.77 & 1.32 \\
\hline 7 & 37.4 & 84.79 & 0.23 & 0.33 & 0.62 \\
\hline 8 & 50.8 & 93.57 & 0.25 & 0.39 & 0.67 \\
\hline 9 & 37.4 & 60.41 & 0.16 & 0.26 & 0.41 \\
\hline $\max$. & 99.60 & 184.32 & 0.50 & 0.77 & 1.32 \\
\hline $\min$. & 37.40 & 60.46 & 0.16 & 0.26 & 0.41 \\
\hline ave. & 58.44 & 110.94 & 0.30 & 0.46 & 0.80 \\
\hline stdev. & 27.86 & 67.24 & 0.18 & 0.26 & 0.51 \\
\hline med. & 50.8 & 93.57 & 0.25 & 0.39 & 0.67 \\
\hline med. abs. div. & 13.4 & 13.72 & 0.04 & 0.06 & 0.1 \\
\hline 10 & 39.2 & 96.12 & 0.26 & 0.37 & 0.70 \\
\hline 11 & 33.8 & 81.64 & 0.22 & 0.31 & 0.60 \\
\hline 12 & 48.4 & 99.36 & 0.27 & 0.40 & 0.72 \\
\hline 13 & 36.6 & 79.96 & 0.22 & 0.32 & 0.58 \\
\hline 14 & 75.4 & 156.97 & 0.42 & 0.63 & 1.13 \\
\hline 15 & 41.8 & 88.43 & 0.24 & 0.35 & 0.65 \\
\hline 16 & 41.6 & 95.20 & 0.26 & 0.37 & 0.69 \\
\hline 17 & 62.6 & 131.73 & 0.36 & 0.53 & 0.96 \\
\hline 18 & 32 & 77.24 & 0.21 & 0.29 & 0.57 \\
\hline $\max$. & 75.40 & 156.97 & 0.42 & 0.63 & 1.13 \\
\hline $\min$. & 32.00 & 77.24 & 0.21 & 0.29 & 0.57 \\
\hline ave. & 45.71 & 100.74 & 0.27 & 0.40 & 0.73 \\
\hline stdev. & 5.09 & 13.35 & 0.04 & 0.06 & 0.09 \\
\hline med. & 41.6 & 95.2 & 0.26 & 0.37 & 0.69 \\
\hline med. abs. div. & 6.8 & 13.56 & 0.04 & 0.05 & 0.09 \\
\hline
\end{tabular}

$$
H_{\text {in }}=\frac{C_{U}}{185 \mathrm{Bqkg}^{-1}}+\frac{C_{T h}}{259 \mathrm{Bqkg}^{-1}}+\frac{C_{K}}{4810 \mathrm{Bqkg}^{-1}}
$$

$\mathrm{H}_{\mathrm{ex}}$ is used to calculate the indoor radiation dose value due to the outward exposure to $\gamma$-radiation released by the natural radionuclides in the formation building substances of the lodging places. Moreover, the internal exposure to ${ }^{222} \mathrm{Rn}$ and its radioactive progeny are managed by $H_{i n}$. The radiation hazard considered as insignificant if both $\mathrm{H}_{\mathrm{ex}}$ and $\mathrm{H}_{\text {in }}$ are less than one [29, 30]; this is very significant to keep the concentration levels of radon and its short-lived daughters low enough for the respiratory organs of humans living comparable to the recorded international levels of 40 Bq m${ }^{-3}$ [10]. For both $\mathrm{H}_{\mathrm{ex}}$ and $\mathrm{H}_{\text {in }}$ to be less than one, the maximum values of $\mathrm{Ra}_{\mathrm{eq}}$ must be less than $370 \mathrm{~Bq} / \mathrm{kg}$ and 185 $\mathrm{Bq} / \mathrm{kg}$, respectively. The estimated results of $\mathrm{H}_{\mathrm{ex}}$ for clay soil samples are ranging from 0.5 to 0.16 with an average value of $0.3(\mathrm{~Bq} / \mathrm{kg})$ in $\mathrm{Abu} \mathrm{Al}$ Khasib and ranging from 0.21 to 0.42 with an average value of $0.27(\mathrm{~Bq} / \mathrm{kg})$ in Ad Dayer. Also, $\mathrm{H}_{\mathrm{in}}$ ranges from 0.26 to 0.77 with an average value of $0.46(\mathrm{~Bq} / \mathrm{kg})$ in $\mathrm{Abu} \mathrm{Al} \mathrm{Khasib} \mathrm{and} \mathrm{ranges} \mathrm{from} 0.29$ to 0.63 with an average value of $0.40(\mathrm{~Bq} / \mathrm{kg})$ in Ad Dayer (Table 7$)$. This implies that the external and internal hazard indices estimated in this study are below the recommended limit.

The radioactivity level index $I_{\gamma}$ is used to monitor radiation inside the human body and to compute the risky level of radionuclides in the human body when exposed to an amount of indoor or outdoor annual effective doses of $\gamma$ radiations from radioactive nuclides in soils. The estimated values of $I_{\gamma}$ should be less than or equal to one to make sure the soil environment is hazard-free. In this work, $I_{\gamma}$ calculated to certify that such radiation does not exceed the world high 
dose values [31]. Values of $I_{\gamma}$ were calculated according to the following formula [32]:

$$
I_{\gamma}=\frac{C_{U}}{150 \mathrm{Bqkg}^{-1}}+\frac{C_{T h}}{100 \mathrm{Bqkg}}+\frac{C_{K}}{1500 \mathrm{Bqkg}^{-1}}
$$

As illustrated in Table $7 I_{\gamma}$ is ranging from 0.41 to 1.32 with an average of 0.8 in Abu Al Khasib and ranging from 0.57 to 1.13 with an average of 0.73 in Ad Dayer. In most soil samples, the calculated values of $I_{\gamma}$ are close to or higher than 1 , which implies that these soil samples should be avoided and not used in agriculture or in building materials [31].

The results show that the increased incidence of cancer and neonatal abnormalities is related to the higher concentration of radionuclides in the soil, as the rates of cancer and deformities were not so high before the wars and the presence of military barracks in those areas until the time that the samples have been collected.

\section{Conclusions}

Estimations on clay soil samples were carried elementally for ${ }^{238} \mathrm{U},{ }^{232} \mathrm{Th},{ }^{226} \mathrm{Ra}$, and ${ }^{40} \mathrm{~K} .18$ samples were collected in a previous work from $\mathrm{Abu} \mathrm{Al}$ Khasib and Ad Dayr districts in Basrah, Iraq, from different depths $(0,30$, and $60 \mathrm{~cm})$. The consequences attained indicate obviously that the mean activities of ${ }^{238} \mathrm{U}$ and ${ }^{226} \mathrm{Ra}$ radionuclides examined in the soil are high as compared to median levels documented worldwide. ${ }^{232} \mathrm{Th},{ }^{40} \mathrm{~K}$ activities are low compared to the world's average levels. In addition to that, the achieved evaluations of the radiation hazard indices due to the activity concentrations of ${ }^{238} \mathrm{U},{ }^{232} \mathrm{Th},{ }^{226} \mathrm{Ra}$, and ${ }^{40} \mathrm{~K}$ indicated that the indices are within normal limits, except the radioactivity level index $I_{\gamma}$, which shows elevated values in most samples. Abu Al Khasib and Ad Dayr can be regarded as areas with elevated back radioactive ground radiation.

\section{Data Availability}

The data used to support the findings of this study are available from the corresponding author upon request.

\section{Conflicts of Interest}

The authors declare that there are no conflicts of interest regarding the publication of this paper.

\section{Disclosure}

This research did not receive specific funding, but was performed as part of the employment of the authors Rasha S. Ahmed, Raghad S. Mohammed, and Rana O. Abdaljalil

\section{References}

[1] UNSCEAR, Sources, Effects and Risks of Ionizing Radiation, 1993.

[2] A. Kurnaz, B. Küçükömeroǧlu, R. Keser et al., "Determination of radioactivity levels and hazards of soil and sediment samples in Firtına Valley (Rize, Turkey)," Applied Radiation and Isotopes, vol. 65, no. 11, pp. 1281-1289, 2007.

[3] E. Svoukis and H. Tsertos, "Indoor and outdoor in situ highresolution gamma radiation measurements in urban areas of Cyprus," Radiation Protection Dosimetry, vol. 123, no. 3, pp. 384390, 2007.

[4] I. F. Al-Hamarneh and M. I. Awadallah, "Soil radioactivity levels and radiation hazard assessment in the highlands of northern Jordan," Radiation Measurements, vol. 44, no. 1, pp. 102-110, 2009.

[5] R. Veiga, N. Sanches, R. M. Anjos et al., "Measurement of natural radioactivity in Brazilian beach sands," Radiation Measurements, vol. 41, no. 2, pp. 189-196, 2006.

[6] O. S. Habib, J. M. A. Al-Diab, A. A. Mohsin et al., "Experience and outcome of population-based cancer registration in BasrahSouthern Iraq in 2005-2008," Asian Pacific Journal of Cancer Prevention, vol. 11, no. 4, pp. 1151-1154, 2010.

[7] R. S. Mohammed and R. S. Ahmed, "Estimation of excess lifetime cancer risk and radiation hazard indices in southern Iraq," Environmental Earth Sciences, vol. 76, no. 7, article no. 303, 2017.

[8] H. R. Saad and D. Al-Azmi, "Radioactivity concentrations in sediments and their correlation to the coastal structure in Kuwait," Applied Radiation and Isotopes, vol. 56, no. 6, pp. 991997, 2002.

[9] E. Tabar, M. N. Kumru, M. Içhedef, and M. M. Saç, "Radioactivity level and the measurement of soil gas radon concentration in Dikili geothermal area, Turkey," International Journal of Radiation Research, vol. 11, no. 4, pp. 253-261, 2013.

[10] UNSCEAR, Effects of Ionizing Radiation: Report to the General Assembly, with Scientific Annexes, vol. 2, 2000.

[11] F. Mireles-Garcia, J. I. Dàvila, L. L. Quirino, J. F. Lugo, J. L. Pinedo, and C. Ríos, "Natural soil gamma radioactivity levels and resultant population dose in the cities of Zacatecas and Guadalupe, Zacatecas, Mexico," Health Physics Journal, vol. 84, no. 3, pp. 368-372, 2003.

[12] A. Rani and S. Singh, "Natural radioactivity levels in soil samples from some areas of Himachal Pradesh, India using $\gamma$ ray spectrometry," Atmospheric Environment, vol. 39, no. 34, pp. 6306-6314, 2005.

[13] C. C. Goddard, "Measurement of outdoor terrestrial gamma radiation in the sultanate of Oman," Health Physics Journal, vol. 82, no. 6, pp. 869-874, 2002.

[14] T. Nasir, H. Al-Sulaiti, and P. H. Regan, "Assessment of radioactivity in some soil samples of qatar by gamma-ray spectroscopy and the derived dose rates," Pakistan Journal of Scientific and Industrial Research Series A: Physical Sciences, vol. 55, no. 3, pp. 128-134, 2012.

[15] T. Santawamaitre, D. Malain, H. A. Al-Sulaiti, M. Matthews, D. A. Bradley, and P. H. Regan, "Study of natural radioactivity in riverbank soils along the Chao Phraya river basin in Thailand," Nuclear Instruments and Methods in Physics Research Section A: Accelerators, Spectrometers, Detectors and Associated Equipment, vol. 652, no. 1, pp. 920-924, 2011.

[16] M. Tzortzis, H. Tsertos, S. Christofides, and G. Christodoulides, "Gamma-ray measurements of naturally occurring radioactive samples from Cyprus characteristic geological rocks," Radiation Measurements, vol. 37, no. 3, pp. 221-229, 2003.

[17] P. Chiozzi, V. Pasquale, and M. Verdoya, "Naturally occurring radioactivity at the Alps-Apennines transition," Radiation Measurements, vol. 35, no. 2, pp. 147-154, 2002. 
[18] T. E. Myrick, B. A. Berven, and F. F. Haywood, "Determination of concentrations of selected radionuclides in surface soil in the U.S," Health Physics Journal, vol. 45, no. 3, pp. 631-642, 1983.

[19] P. Killeen, "Gamma ray spectrometric methods in uranium exploration-application and interpretation; in Geophysics and Geochemistry in the Search for Metallic Ores," in Economic Geology Report, P. J. Hood, Ed., pp. 163-229, Geological Survey of Canada, 1963.

[20] J. Al-Jundi, B. A. Al-Bataina, Y. Abu-Rukah, and H. M. Shehadeh, "Natural radioactivity concentrations in soil samples along the Amman Aqaba Highway, Jordan," Radiation Measurements, vol. 36, no. 1-6, pp. 555-560, 2003.

[21] S. Dragović, L. Janković, A. Onjia, and G. Bačić, "Distribution of primordial radionuclides in surface soils from Serbia and Montenegro," Radiation Measurements, vol. 41, no. 5, pp. 611616, 2006.

[22] B. L. Dickson and K. M. Scott, "Interpretation of aerial gammaray surveys - adding the geochemical factors," AGSO Journal of Australian Geology and Geophysics, vol. 17, no. 2, pp. 187-200, 1997.

[23] I. A. Alnour, N. Ibrahim, and I. Hossain, "Concentrations of ${ }^{214} \mathrm{~Pb},{ }^{214} \mathrm{Bi}$ in $238 \mathrm{U}$ series and ${ }^{208} \mathrm{Tl},{ }^{228} \mathrm{Ac}$ in ${ }^{232} \mathrm{Th}$ series in granite rock in (Kadugli) Sudan," Indian Journal of Pure \& Applied Physics, vol. 50, no. 5, pp. 285-288, 2012.

[24] S. S. Wong, Introductory Nuclear Physics, Wiley-VCH, New York, NY, USA, 2nd edition, 1999.

[25] L. Xinwei, W. Lingqing, J. Xiaodan, Y. Leipeng, and D. Gelian, "Specific activity and hazards of Archeozoic-Cambrian rock samples collected from the Weibei area of Shaanxi, China," Radiation Protection Dosimetry, vol. 118, no. 3, pp. 352-359, 2006.

[26] J. Beretka and P. J. Mathew, "Natural radioactivity of australian building materials, industrial wastes and by-products," Health Physics Journal, vol. 48, no. 1, pp. 87-95, 1985.

[27] OECD, Exposure to radiation from the natural radioactivity in building materials. a Group of Experts of the Organization for Economic Cooperation and Development, Nuclear Energy Agency, Paris, 1979.

[28] M. N. Alam, M. M. H. Miah, M. I. Chowdhury et al., "Radiation dose estimation from the radioactivity analysis of lime and cement used in Bangladesh," Journal of Environmental Radioactivity, vol. 42, no. 1, pp. 77-85, 1999.

[29] N. Q. Huy and T. V. Luyen, "Study on external exposure doses from terrestrial radioactivity in Southern Vietnam," Radiation Protection Dosimetry, vol. 118, no. 3, pp. 331-336, 2006.

[30] A. K. Mahur, R. Kumar, M. Mishra et al., "Study of radon exhalation rate and natural radioactivity in soil samples collected from East Singhbhum Shear Zone in Jaduguda U-Mines Area, Jharkhand, India and its radiological implications," Indian Journal of Pure \& Applied Physics, vol. 48, no. 7, pp. 486-492, 2010.

[31] F. S. Al-Saleh and B. Al-Berzan, "Measurements of natural radioactivity in some kinds of marble and granite used in Riyadh region," Journal of Nuclear and Radiation Physics, vol. 2, pp. 25-36, 2007.

[32] S. Issa, M. Uosif, and R. Elsaman, "Gamma radioactivity measurements in Nile river sediment samples," Turkish Journal of Engineering \& Environmental Sciences, vol. 37, no. 1, pp. 109122, 2013. 

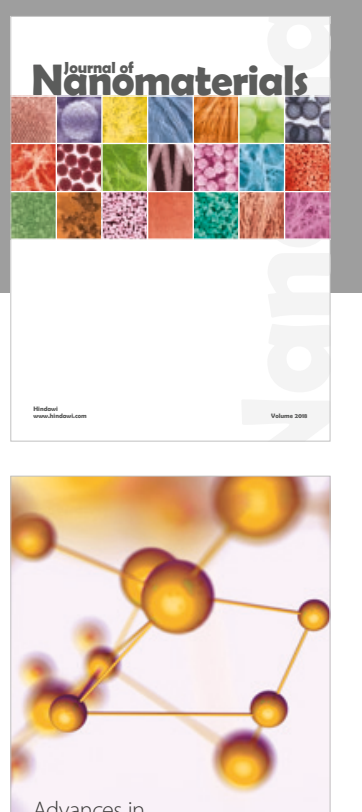

Physical Chemistry
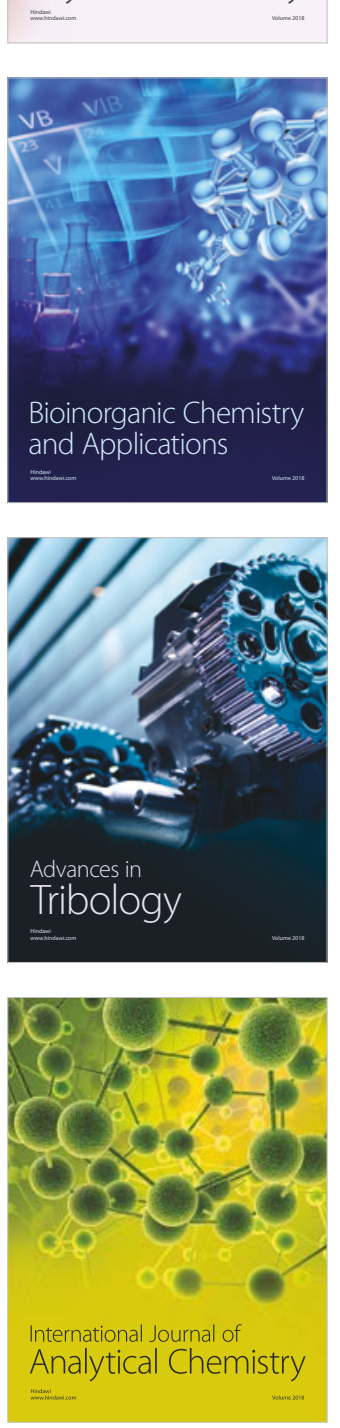

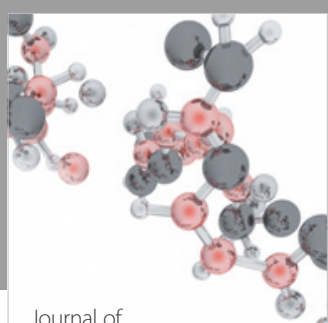

Analytical Methods

in Chemistry

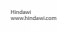

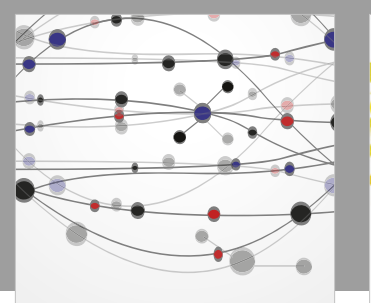

The Scientific World Journal

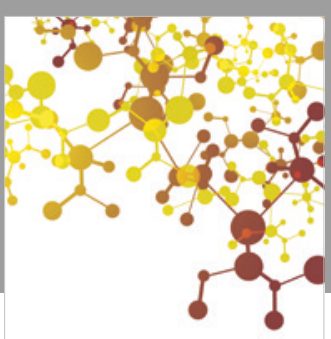

Journal of

Applied Chemistry
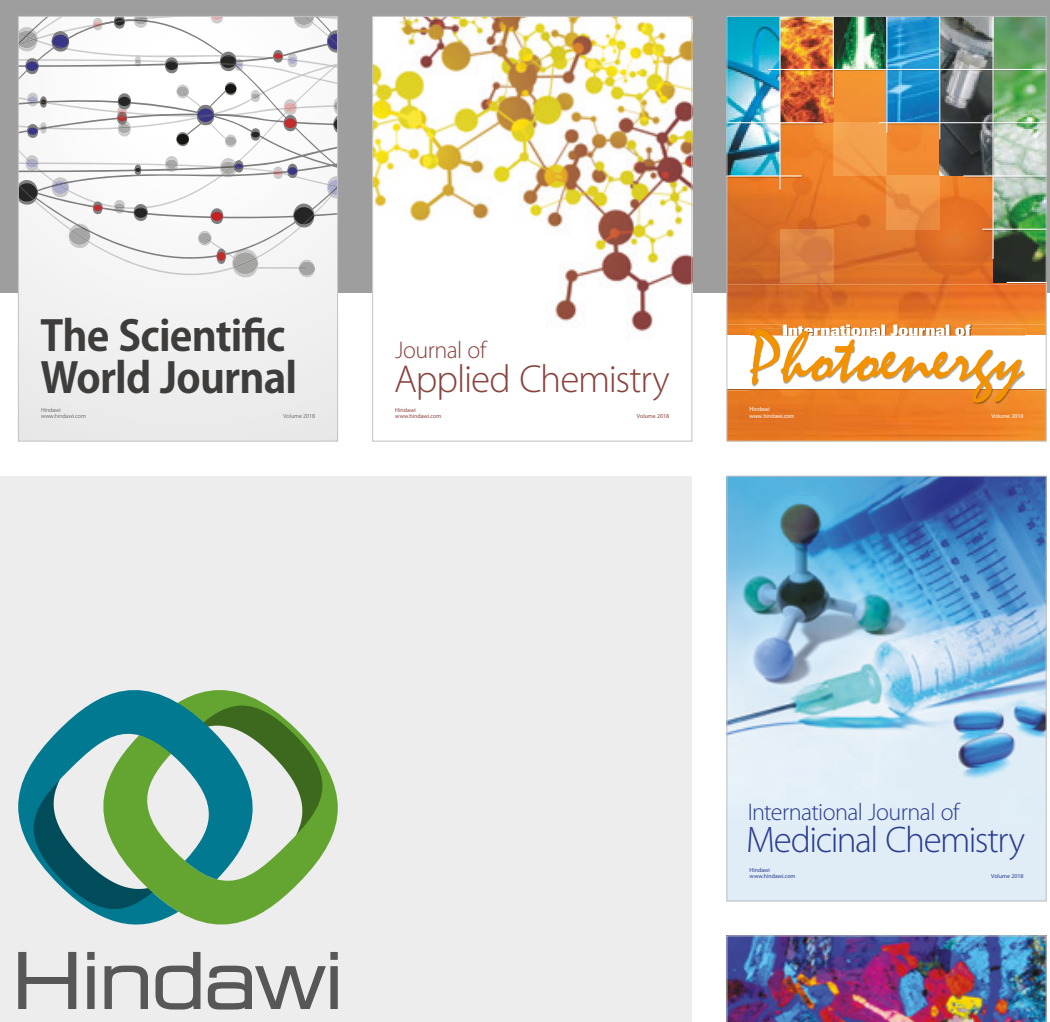

Submit your manuscripts at

www.hindawi.com
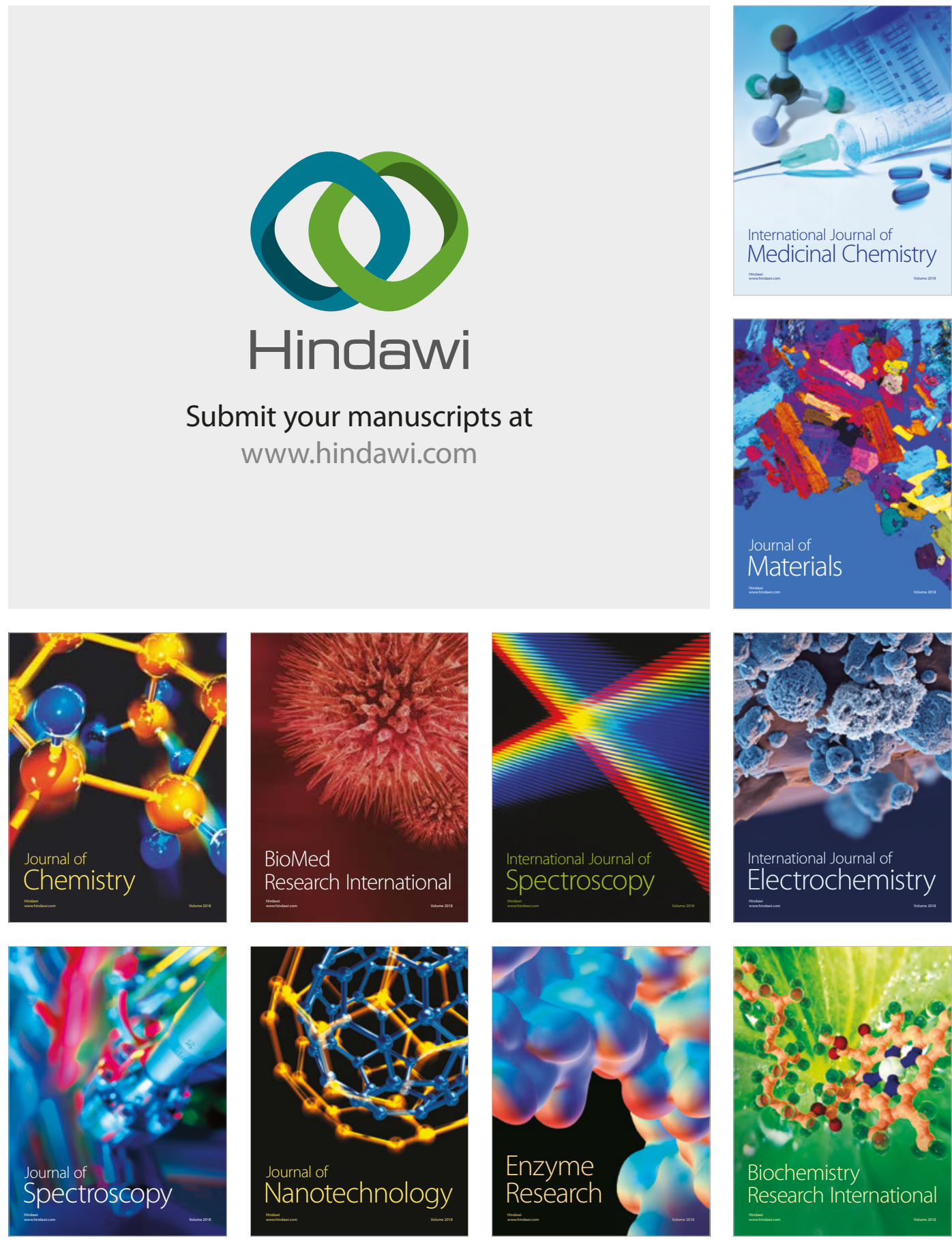
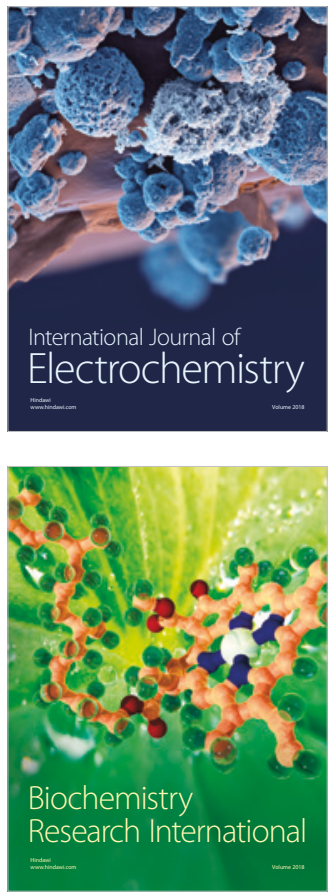